Changes in Permeability and Fluld Chemistry of the Topopah Spring Hember of the Paintbrush Tuff (Nevada Test Site) When Held in a Temperature Gradient: Sumary of Results

D. E. Moore

C. A. Morrow

J. D. Byerlee

June 1984

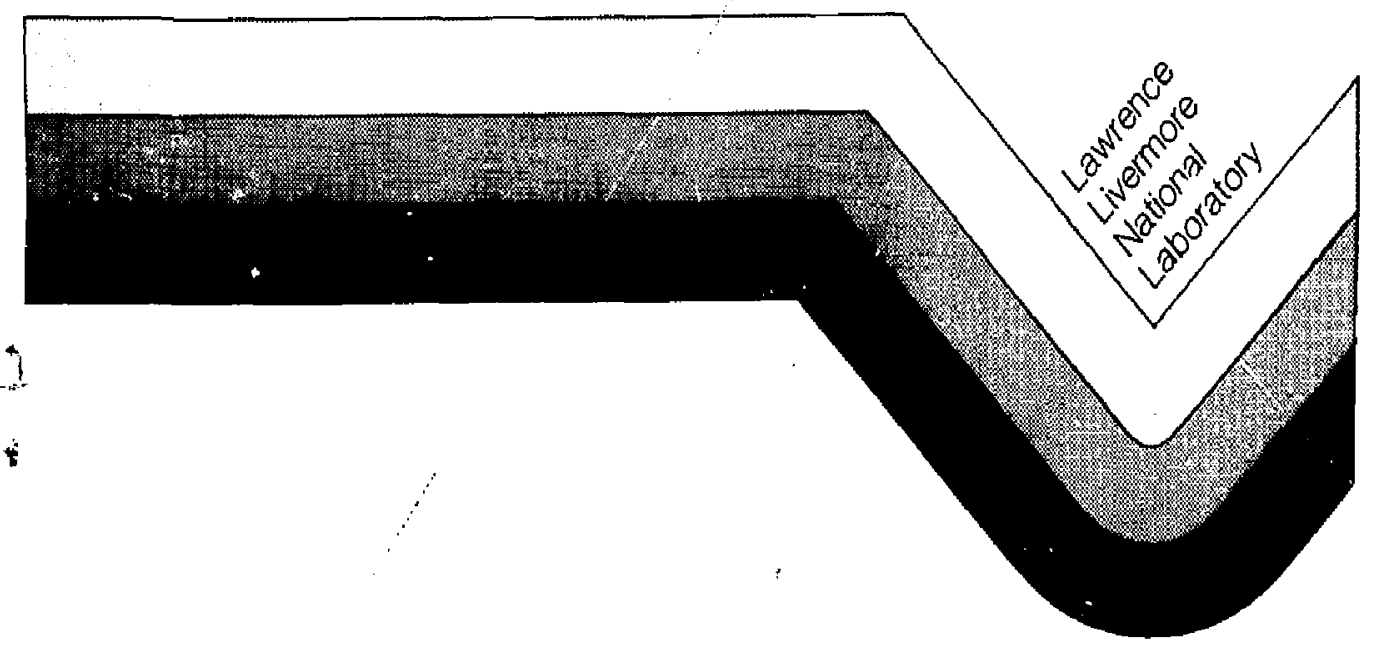


NOTICE

Work performed under the auspices of the U.S. Departmeni of fnergy by the lantence Livemare laboratory under coniract number W-7405-ENY(i-48.

This document wis prepured as an accoynl of wolk

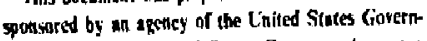
ment. Neither the linited States Govemmenl nor any agency thereol, nor any of their employees, makes sny matranty, expressed or implied, or assames any legal liability or responsibility for the accurscy, compleleness, or usefulness of any information, apporntus. product, or process discloscd, or represents thal its use nould not infringe privately awned rights. Refcrense herefin to any specific commencial producl, process, or sertice by tradr mamie, tsadematk. manulacturce, or otherwise, does not nectsatily constitute or imply its endorsement, recommendalian, or favoring by the U/nited Stales Government or any ggency thereof. The riews and opizions of authors expressed hercin do not mecessarily stale or reflect those of the Uailed States Goverament or any agency thereof. 
UNITEO STATES DEPARTMENT OF THE INTERIOR GEOLOGICAL SURVEY

\section{CHANGES IN PERAEABILITY AND FLUID CHEMISTRY OF THE TOPOPAH SPRING MEMBER OF THE PAINTBRUSH TUFF (NEVADA TEST SITE) \\ WHEN HELD IN A TEMPERATURE GRADIENT: SUMMARY OF RESULTS}

D. E. Moore, C. A. Morrow, and J. D. Byerlee

Open-File Report

$84-273$

This report is preliminary and has not been reviewed for conformity with Geological Survey editorial standards

or stratigraphic nomenclature 


\section{INTROOUCTION}

A series of permeability experiments has been conducted to model the flow of groundwater away from canisters heated by radioactive decay at a nuclear waste disposal site in tuffaceous rock. The purpose of the study was to determine the effects of localized heating around the canisters on the reoository rock and associated groundwaters. This work was performed as a support study for the Nevada Nuclear Waste Storage Investigations (NNWSI) project under a contract to Lawrence Livermore Laboratory which is conducting waste packaging studies. Studies concentrated on two tuff units from the Nevada Test Site which are being evaluated as possible disposal horizons: the Bullfrog Member of the Crater Flat Tuff, and the Topopah Spring Member of the Paintbrush Tuff. Results for the Bullfrog Member have been presented in Morrow et al. (1983) and Byerlee et al. (1983). This paper reports the gemeability and groundwater chemistry results for the Topopah Spring Member and compares those results with the previous work on Bullfrog.

\section{SAMPLE DESCRIPTION}

The samples of tuff from the Topopah Spring Member were collected from surface exposures. Overal\}, the rocks are tightly welded and dense; however, these outcrop samples also contain some open, quartz- and calcite-lined cavities, up to $5 \mathrm{~cm}$ wide, that extend for many centimeters along the bedding direction of the tuff. 
The tuff is densely welded, devitrified, and nonzeolitized, with some aphanitic to porphyritic volcanic lithic fragmenis and scarce phenocrysts. The phenocrysts are principally plagioclase and opaques and, less comonly, potash feldspar, embayed quartz and altered, dark brown biotite. The groundmass consists of cristobalite and potassium feldspar, as identified by $x$-ray diffraction analysis. These minerals typically are microcrystalline, occurring in spherulites that, according to waters and Carroll (1981), formed as primary devitrification products during the initial cooling of the tuff. Coarsergrained patches of subhedral to euhedral quartz and potassium feldspar in the groundmass are considered by Waters and Carroll (1981) to have crystallized during a late diagenetic stage. The growth of quartz and minor calcite on the larger cavity walls probably also is associated with this later diagenetic event.

\section{EXPERIMENTAL PROCEDURE}

The experimental design is shown in Figure 1. Cylindrical samples of the Topopah Spring Member were prepared, each one $7.62 \mathrm{~cm}$ in diameter and $8.89 \mathrm{~cm}$ long, with a $1.27 \mathrm{~cm}$ diameter borehole in the center. A coiled resistence heater placed within the borehole produced a temperature gradient between the center and outside of the rock. Water flowed radially through the tuff from the higher temperature borehole to the lower temperature outer edge in response to a small differential pore pressure gradient applied between the center and outside of the rock. The water used in these experinients was a natural groundwater ( $0-13)$ collected from the Nevada Test Site; its chemical composition is listed in Table 1. The J-13 water used for experiment 1 was obtained at a 


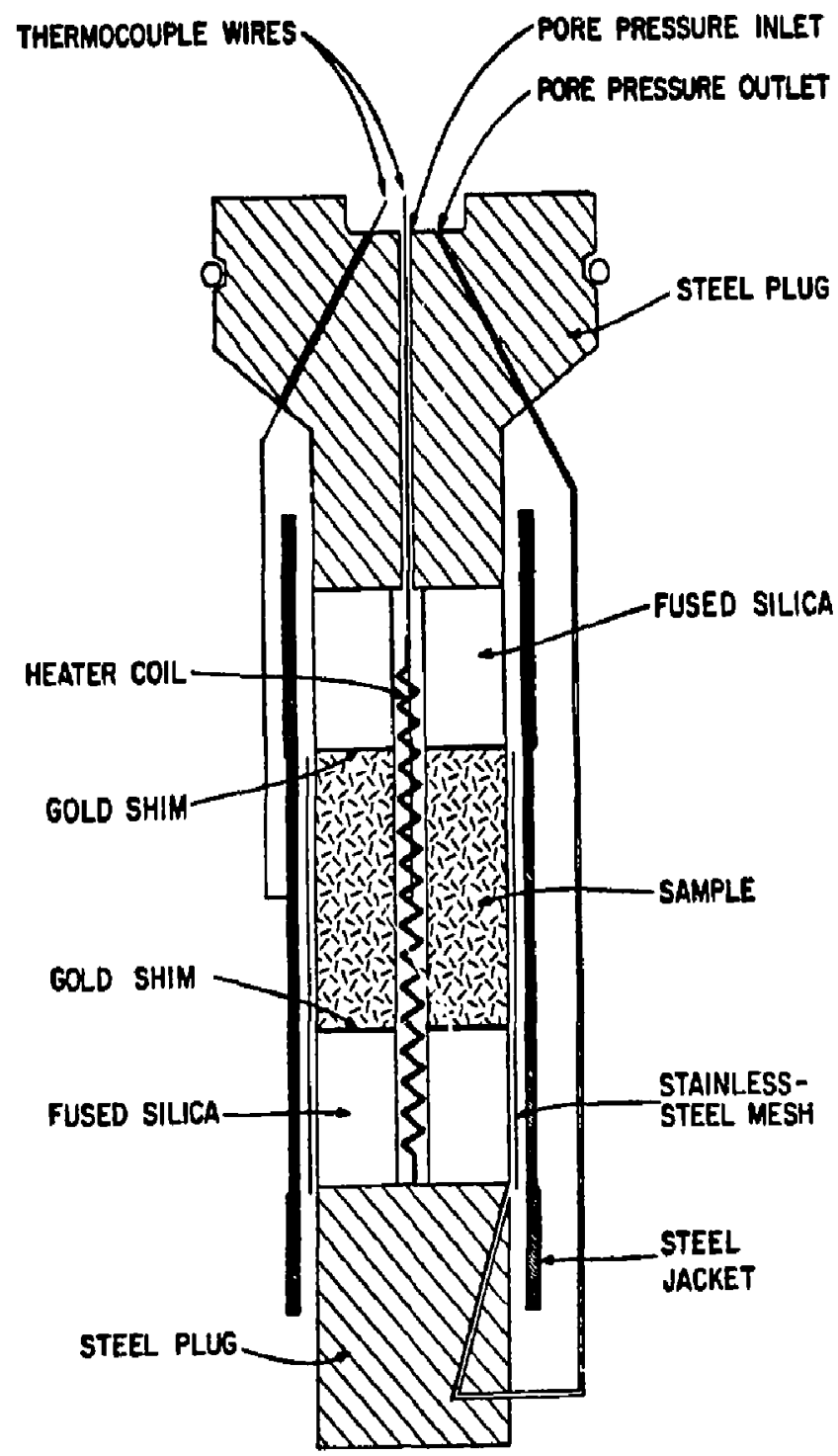

Figure 1. Experimental assembly. 
TABLE 1. COMPOSITION OF J13 GROUNDWATER FROM THE NEVADA TEST SITE

Exp. 1

$\mathrm{pH}$

$\mathrm{SiO}_{2}$

$\mathrm{Na}$

K $\quad(\mathrm{mg} / \mathrm{L})$

$\mathrm{Mg}$

$\mathrm{Ca}$

$\mathrm{HCO}_{3}^{*}$

$\mathrm{SO}_{4}$

NO

$\mathrm{F}$

C1

Cation Sum (meq/L)

Anion Sum (meq/L)

2.796

2.2

8.1

2.784

Balance

$-0.4 \%$
2.773

2.810

$-1,3 \%$

Exps. 2 and 3

7.60

57

44

3.7

2.0

12

120

19

8.3

2.2

7.0

* Determined by both carbon analyzer and titration methods 
different time from that used in the other two experiments and it has a slightly different composition, as indicated in the table. Cores were drilled such that flow would be along the direction of bedding of the tuff. All exposed metal in the high temperature borehole area was gold plated to prevent fluid contamination. Gold shims at the ends of the sample prevented water from leaking between the tuff and the fused silica cylinders that served as themal insulators.

The experimental design necessitated the presence of a good thermal insulator on either side of the rock sample. Such insulating cylinders also needed to be impermeable, so that water flowed only through the rock sample. The fused silica cylinders that were used in the experiments best satisfied both these requirements. Because the insulators were exposed to the inlet fluids, the possibility existed that the fluids would acquire silica from the insulating cylinders. However, as described in Byerlee et al. (1983) and Keith et al. (1983), several lines of evidence suggest that the cylinders were not a source of excess silica in solution.

A stainless steel mesh was wrapped around the outside of the sample to a tota! thickness of $0.63 \mathrm{~mm}$, to allow drainage of the pore fluids that had passed through the rock. In this way, the Cu-Ni plated jacket surrounding the sample assembly did not interfere with fluid flow, while still sealing the sample from the confining pressure fluid. Pore pressure and hydrostatic confining pressure were held constant by a computer-controlled servo-mechan ism.

The initial permeability of each tuff cylinder was measured at room temperature. Following that, fluid flow was halted while the sample was heated. Within approximately an hour's time a stable temperature gradient was established across the tuff cylinders and flow was resumed. Samples of 
pore fluids were collected at intervals during both the room-temperature and heated experiments to detemine changes in water chemistry as a result of interaction with the tuffs.

Three experiments at different temperatures were conducted using the Topopah Spring Member. The conditions are summarized in Table 2. The $150^{\circ} \mathrm{C}$ and $90^{\circ} \mathrm{C}$ borehole temperatures of experiments 1 and 2 are expected temperatures of heating around canisters disposed in the Topopah Spring Member. The $250^{\circ} \mathrm{C}$ borehole temperature of experiment 3, perhaps high for burial in Topopah, was chosen to provide a comparison with previous experiments run at that temperature on granodiorite, quartzite, and the Bullfrog Member of the Crater Flat Tuff. The confining pressures of 300 bars and pore pressures of 100 bars used in each experiment simulated a disposal depth of around $1.2 \mathrm{~km}$. These pressures were chosen to allow a direct comparison with the Bullfrog experiments. An attempt was made to maintain a pore pressure differential of 1.5 bar in each experiment. However, sample 3 contained a throughgoing void, making it impossible to establish a measurable pore pressure gradient across the rock without an unreasonably high flow rate. Therefore, pemeability measurements were nct made on that sample. Instead, in the first part of experiment 3 , the effects of time at a constant flow rate $\left(2 \times 10^{-4} \mathrm{~cm}^{3} / \mathrm{sec}\right)$ on groundwater chemistry were investigated. After about 17 days, the effects of flow rate on the pore fluid composition were investigated by varying the flow rate over 3 orders of magnitude between $2 \times 10^{-5} \mathrm{~cm}^{3} / \mathrm{sec}$ and $2 \times 10^{-2} \mathrm{~cm}^{3} / \mathrm{sec}($ Table 3). Fluid samples were collected at the end of each period of flow at a given rate.

The effect of contact time between the pore fluids and heated rock cylinder also was investigated in experiment ?, but in a slightly different way from 
TABLE 2. EXPERIMENTAL CONDITIONS

Experiment No.

1

2

3

\begin{tabular}{lccc}
\hline \hline & & & \\
& 150 & 90 & 250 \\
Borehole temperature $\left({ }^{\circ} \mathrm{C}\right)$ & 50 & 36 & 83 \\
$\begin{array}{l}\text { Jacket temperature }\left({ }^{\circ} \mathrm{C}\right) \\
\text { Conf ining pressure (bars) }\end{array}$ & 300 & 300 & 300 \\
$\begin{array}{l}\text { Pore pressure (bars) } \\
\text { Differential pore pressure } \\
\text { (bars) }\end{array}$ & 100 & 100 & 100 \\
$\begin{array}{l}\text { Pore fluid } \\
\text { Duration of experiment (days) } \\
\text { Average flow rate }\left(\mathrm{cm}^{3} / \mathrm{sec}\right)\end{array}$ & $1.15 \times 10^{-3}$ & $1.45 \times 10^{-3}$ & $2 \times 10^{-4}$ \\
\hline
\end{tabular}


TABLE 3, CHANGES IN FLUID FLOW DURING EXPERIMENTS 2 and 3.

\section{EXPERIMENT 2}

Flow was halted during the following time periods:
Time
Interva?
3.84 to 5.92 Days
50 hrs
6.84 to 7.88 Days
$25 \mathrm{hrs}$
9.73 to 13.9 Days
100 hrs

\section{EXPERIMENT 3}

$\begin{array}{ll}\frac{\text { Time }}{0 \text { to } 16.74 \text { Days }} & 2 \times 10^{-4} \mathrm{~cm}^{3} / \mathrm{sec} \\ 16.76-17.00 \text { Days } & 2 \times 10^{-3} \mathrm{~cm}^{3} / \mathrm{sec} \\ 17.02-17.06 \text { Days } & 2 \times 10^{-2} \mathrm{~cm}^{3} / \mathrm{sec} \\ 17.08-17.73 \text { Days } & 2 \times 10^{-4} \mathrm{~cm}^{3} / \mathrm{sec} \\ 17.75-20.73 \text { Days } & 2 \times 10^{-5} \mathrm{~cm}^{3} / \mathrm{sec}\end{array}$


experiment 3. In this case, flow was halted for intervals of 25,50 , and 100 hours during the course of the experiment (Table 3). Fluids were collected immediately following each period without flow, in order to sample the pore fluids that had been in contact with the tuff during that time.

\section{PERMEABILITY: CALCULATION AND ?ESULTS}

The variations in frmeability w th time for experiments 1 and 2 were determined from measured chariges in the miss flow rate over the constant pore pressure differential. The radial flow form of Darcy's Law was solvod for perrieability and integrated over the radius irom ine inner borehole $\left(r_{1}\right)$ to the outer edge of the sample $\left(r_{2}\right)$, as follows:

$$
k=\frac{Q}{2 \pi \ell d F} \int_{r_{1}}^{r_{2}} \frac{v(r)}{r} d r
$$

$Q_{m}$ is the mass flow rate, $i$ the length of the sample, $k$ the perrieability, $r$ the sample radius, and $\Delta^{p}$ the fluid pressure gradient between th: center and outside of the sample. $v(r)$ is the dynamic viscosity of water, which is a function of temperature and therefore of radius in these experimerits. Changes in $v$ across the samples are taken into accouni in the computer program used to calculate permeability. The values of $v$ used in tire calculations are obtained from published steam tables. The permeabilities so calculated describe the bulk permeability properties of the rock cylinders.

The clanges in permeability of the tuffs from the first two experiments are plotted in figure 2. The initial, room-temperature permeabilities of 


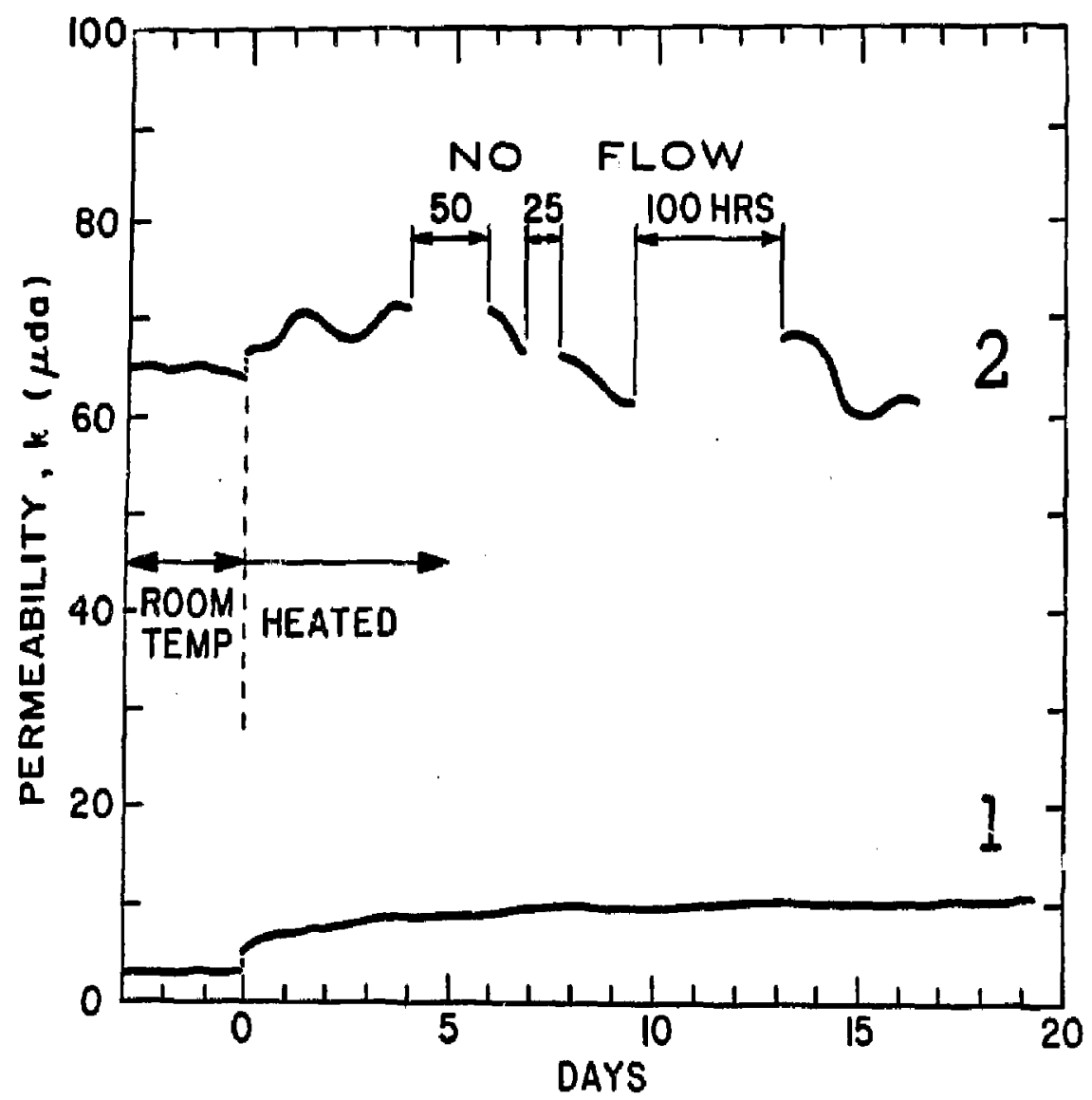

Figure 2. Changes in permeability of the Topopah Spring Tuff as a function of time. Experiment 1: $150^{\circ} \mathrm{C}$ borehole temperature; Experiment 2: $90^{\circ} \mathrm{C}$ borehole temperature. 
samples 1 and 2 were 3 and $65 \mu d a$, respectively, the large difference perhaps being due to variations in their internal void and fracture geometries. In response to thermal cracking accompanying initial heating to $150^{\circ} \mathrm{C}$ (borehole temperature), the permeability of tuff cylinder 1 increased imediately to $8 \mu d a$. Following that, the permeability rose at a much slower rate over the first 5 days and then stabilized at a value of approximately $10 \mu d a$. In experiment 2, the permeability of the tuff remained between 60 and $70 \mu d a$ even after heating to a borehole temperature of $90^{\circ} \mathrm{C}$.

\section{FLUID CHEMISTRY}

\section{Sample Collection and Analytical Techniques}

A $2 \mathrm{ml}$ sample of the fluids discharged at the low-temperature, outer edge of the tuff cylinders was collected at intervals during the experiments. Immediately upon collection, each sample was passed through a $0.45 \mu \mathrm{m}$ membrane filter and a $0.25 \mathrm{ml}$ aliquot was separated for $\mathrm{SiO}_{2}$ analysis. A second, $1 \mathrm{ml}$ aliquot for cation analyses was diluted to $5 \mathrm{ml}$ with distilled water and acidified to a pH of about 2, with 10-15 $\mu \mathrm{L}$ of a $1: 1$ dilution of concentrated $\mathrm{HCl}$. Room-temperature oH measurements were then mate on the remaining fluid, which was later used for anion detcrminations.

The fluid samples were analyzed for 13 dissolved species. The fluids reserved for silica analysis were digested overnight in a $1 \mathrm{~N} \mathrm{NaOH} \mathrm{solution} \mathrm{and}$ then enalyzed by standard spectrophotometric techniques, using the melybdate blue method (ASTM, 1974, pp. 401-2). The total dissolved inorganic carbon content was determined with a carbon analyzer. The anions $\mathrm{Cl}, \mathrm{F}, \mathrm{SO}_{4}, \mathrm{PO}_{4}$ 
and, where present, $\mathrm{NO}_{2}$ and $\mathrm{NO}_{3}$, were obtained using ion chromatographic techniques. Oue to the high of of the buffer used in the ion chromatograph system, $\mathrm{F}$ concentrations may be at a minimum. The cations $\mathrm{Na}, \mathrm{Ca}, \mathrm{K}$, and $\mathrm{Mg}$ were determined using standard atomic absorption techniques.

For the first time in this series of pemeability experiments related to nuclear waste disposal studies (Moore et al., 1983; Byerlee et al., 1983), Al concentrations in the discharged fluids were abtained, using an atomic absorption graphite furnace technique developed by T. S. Presser of the U.S. Geological Survey to accomodate the small sample size. The acidified sample was atomized at a temperature of $2450^{\circ} \mathrm{C}$ in a pyrolytic graphite tube. $1.3 \mathrm{ml}$ of solution was used to obtain two signal measurements in the range of 5 to $100 \mu \mathrm{g} / \mathrm{I} \mathrm{AT}$. The analytical conditions evolved during the series of experiments. Aluininum values given are a qualified total aluminum concentration, i.e., filtered through $0.45 \mu \mathrm{m}$ menbrane filter at $25^{\circ} \mathrm{C}$. These valuss are not to be equated with either the rapidly reacting equilibrium species if aluminum describec by R. B. Barnes (1975) nor a total including a'l colloidal suspended material. It is rather a compromise value chosen to deal with the problems of aluminosilicate speciation and saturation in a temperature gradient (Presser. written comunication, 1984).

\section{Results}

The resuits of these analyses are listed in Table $\%$. The solution balances for all samples from experiments 1 and 2 are within $\pm 10 \%$, and the majority are within $\pm 4 \%$. In experiment 3 , the fluids reserved for anion analysis became unstabie and produced a small amount of precipitate. As a result, the surns of 
TABLE 4 Chemical Analyses (mg/L) of fluids collected during experiments on Topopah Spring Tuff.

\begin{tabular}{|c|c|c|c|c|c|c|c|c|c|c|c|c|c|c|c|c|}
\hline & Days & $\left(25^{\circ} \mathrm{CH}\right)$ & $\mathrm{SiO}_{2}$ & $\mathrm{Na}$ & $k$ & $\mathrm{Mg}$ & $\mathrm{Ca}$ & A 1 & $\mathrm{HCO}_{3}$ & $\mathrm{SO}_{4}$ & $\mathrm{NO}_{2}$ & $\mathrm{NO}_{3}$ & $\mathrm{PO}_{4}$ & $F$ & $\mathrm{Cl}$ & $\underset{\left(\begin{array}{c}8 \times 1 \\
(\%)\end{array}\right.}{ }$ \\
\hline $\begin{array}{c}\text { EXPER IMENT } \\
1 \\
\text { Room-T emperature }\end{array}$ & $\begin{array}{r}0.97 \\
5.80 \\
10.80 \\
13.80\end{array}$ & $\begin{array}{l}7.60 \\
7.66 \\
7.64 \\
7.55\end{array}$ & $\begin{array}{l}42 \\
37 \\
37 \\
42\end{array}$ & $\begin{array}{l}53 \\
45 \\
42 \\
42\end{array}$ & $\begin{array}{l}13 \\
21 \\
25 \\
27\end{array}$ & $\begin{array}{l}2.2 \\
1.2 \\
1.5 \\
1.8\end{array}$ & $\begin{array}{l}22 \\
24 \\
26 \\
27\end{array}$ & $\begin{array}{c}\text { NA } \\
\text { NA } \\
\text { NA } \\
0.23\end{array}$ & $\begin{array}{l}170 \\
170 \\
180 \\
180\end{array}$ & $\begin{array}{l}27 \\
28 \\
27 \\
25\end{array}$ & $\begin{array}{c}4.5 \\
- \\
-\end{array}$ & $\begin{array}{c}6.2 \\
= \\
- \\
-\end{array}$ & $\begin{array}{l}1.7 \\
2.4 \\
2.5 \\
4.7\end{array}$ & $\begin{array}{l}2.8 \\
2.0 \\
2.0 \\
2.1\end{array}$ & $\begin{array}{l}19 \\
17 \\
15 \\
13\end{array}$ & $\begin{array}{l}-8.9 \\
-6.1 \\
-5.2 \\
-1.4\end{array}$ \\
\hline $\begin{array}{l}\text { Heated Run }\left(150^{\circ} \mathrm{C}\right. \\
\left.\text { borehole; } 50^{\circ} \text { jacket }\right)\end{array}$ & $\begin{array}{r}0.15 \\
0.40 \\
1.11 \\
2.13 \\
3.14 \\
3.86 \\
5.86 \\
7.94 \\
8.94 \\
10.85 \\
11.85 \\
12.85 \\
13.85 \\
15.92 \\
17.85 \\
19.85\end{array}$ & $\begin{array}{l}7.52 \\
8.09 \\
7.90 \\
7.90 \\
7.79 \\
7.63 \\
7.62 \\
6.40 \\
7.54 \\
7.57 \\
7.12 \\
7.38 \\
6.90 \\
7.73 \\
7.38 \\
7.38\end{array}$ & $\begin{array}{r}86 \\
90 \\
87 \\
90 \\
82 \\
95 \\
95 \\
87 \\
100 \\
100 \\
100 \\
100 \\
96 \\
95 \\
100 \\
110\end{array}$ & $\begin{array}{l}46 \\
46 \\
44 \\
43 \\
45 \\
43 \\
43 \\
44 \\
43 \\
45 \\
44 \\
44 \\
43 \\
45 \\
44 \\
44\end{array}$ & $\begin{array}{l}31 \\
26 \\
26 \\
18 \\
17 \\
19 \\
18 \\
14 \\
14 \\
13 \\
14 \\
13 \\
13 \\
11 \\
12 \\
14\end{array}$ & $\begin{array}{l}1.1 \\
1.1 \\
0.99 \\
0.84 \\
0.78 \\
0.80 \\
0.68 \\
0.70 \\
0.61 \\
0.67 \\
0.00 \\
0.59 \\
0.61 \\
0.57 \\
0.61 \\
0.57\end{array}$ & $\begin{array}{l}17 \\
17 \\
18 \\
19 \\
19 \\
20 \\
18 \\
19 \\
18 \\
18 \\
18 \\
17 \\
18 \\
17 \\
17 \\
17\end{array}$ & $\begin{array}{l}0.16 \\
0.06 \\
0.04 \\
0.21 \\
0.12 \\
0.08 \\
0.15 \\
0.06 \\
0.13 \\
0.04 \\
0.10 \\
0.06 \\
0.11 \\
0.11 \\
0.31 \\
0.11\end{array}$ & $\begin{array}{l}170 \\
160 \\
160 \\
140 \\
140 \\
140 \\
140 \\
140 \\
140 \\
140 \\
130 \\
140 \\
140 \\
140 \\
140 \\
140\end{array}$ & $\begin{array}{l}22 \\
20 \\
22 \\
21 \\
20 \\
20 \\
20 \\
20 \\
20 \\
19 \\
19 \\
19 \\
19 \\
19 \\
19 \\
19\end{array}$ & $\begin{array}{l}- \\
- \\
- \\
0.28 \\
0.31 \\
0.43 \\
2.0 \\
2.2 \\
2.2 \\
2.4 \\
2.4 \\
2.5 \\
1.7 \\
1.8 \\
0.22 \\
0.10\end{array}$ & $\begin{array}{c}0.64 \\
- \\
- \\
1.2 \\
1.1 \\
0.85 \\
1.0 \\
0.71 \\
0.95 \\
0.86 \\
0.75 \\
- \\
0.53 \\
- \\
- \\
-\end{array}$ & $\begin{array}{l}6.5 \\
4.7 \\
4.0 \\
2.6 \\
4.2 \\
5.7 \\
5.1 \\
2.5 \\
2.8 \\
1.5 \\
2.2 \\
1.7 \\
1.3 \\
0.77 \\
0.57 \\
2.6\end{array}$ & $\begin{array}{l}2.0 \\
1.9 \\
2.1 \\
2.2 \\
2.2 \\
2.2 \\
2.2 \\
2.2 \\
2.2 \\
2.2 \\
2.1 \\
2.2 \\
2.2 \\
2.3 \\
2.2 \\
2.2\end{array}$ & $\begin{array}{c}13 \\
10 \\
12 \\
9.7 \\
9.9 \\
11 \\
9.9 \\
8.4 \\
8.8 \\
8.1 \\
8.7 \\
8.8 \\
8.5 \\
7.3 \\
8.5 \\
8.9\end{array}$ & $\begin{array}{r}-4.7 \\
1.2 \\
-2.6 \\
4.3 \\
4.6 \\
2.7 \\
-0.7 \\
2.6 \\
-1.1 \\
3.1 \\
6.8 \\
-0.3 \\
0.9 \\
2.1 \\
2.7 \\
1.2\end{array}$ \\
\hline
\end{tabular}

$N A=$ Not Analyzed. 
TABLE 4 Chemical Analyses (mg/L) of fluids collected durirgexperiments on Topopah Spring Tuff (continued).

$\begin{array}{llllllllllllllll}\text { Days } & \left(25^{\circ} \mathrm{C}\right) & \mathrm{SiO}_{2} & \mathrm{Na} & \mathrm{K} & \mathrm{Mg} & \mathrm{Ca} & \mathrm{A}] & \mathrm{HCO}_{3} & \mathrm{SO}_{4} & \mathrm{NO}_{2} & \mathrm{NO}_{3} & \mathrm{PO}_{4} & \mathrm{~F} & \mathrm{Cl} & (\%)\end{array}$

\begin{tabular}{|c|c|c|c|c|c|c|c|c|c|c|c|c|c|c|c|c|}
\hline \multicolumn{17}{|l|}{$\begin{array}{c}\text { EXPER IMENT } \\
2\end{array}$} \\
\hline Room-Temperature & $\begin{array}{l}0.02 \\
0.74 \\
1.71 \\
5.79\end{array}$ & $\begin{array}{l}6.94 \\
7.86 \\
8.00 \\
7.67\end{array}$ & $\begin{array}{l}54 \\
42 \\
44 \\
49\end{array}$ & $\begin{array}{l}50 \\
44 \\
41 \\
43\end{array}$ & $\begin{array}{l}21 \\
15 \\
14 \\
9.8\end{array}$ & $\begin{array}{l}1.8 \\
1.5 \\
1.6 \\
1.7\end{array}$ & $\begin{array}{l}12 \\
15 \\
18 \\
20\end{array}$ & $\begin{array}{c}\text { NA } \\
\text { NA } \\
\text { NA } \\
0.02\end{array}$ & $\begin{array}{l}140 \\
130 \\
140 \\
160\end{array}$ & $\begin{array}{l}23 \\
21 \\
18 \\
19\end{array}$ & $\begin{array}{c}1.7 \\
0.57 \\
1.1 \\
-\end{array}$ & $\begin{array}{c}6.6 \\
8.4 \\
4.2 \\
-\end{array}$ & $\begin{array}{l}1.2 \\
2.0 \\
2.1 \\
1.5\end{array}$ & $\begin{array}{l}2.8 \\
2.3 \\
2.2 \\
2.2\end{array}$ & $\begin{array}{r}14 \\
11 \\
8.9 \\
8.3\end{array}$ & $\begin{array}{l}-1.1 \\
-1.2 \\
-0.7 \\
-4.6\end{array}$ \\
\hline $\begin{array}{l}\text { Heated Run }\left(90^{\circ} \mathrm{C} \text { bore- }\right. \\
\text { hole; } 36^{\circ} \text { jacket) } \\
\text { after: } \\
50 \text { hrs no-flow } \\
25 \text { hrs no-flow } \\
100 \text { hrs no-flow }\end{array}$ & $\begin{array}{r}0.88 \\
1.88 \\
3.11 \\
6.01 \\
7.97 \\
13.96 \\
16.91\end{array}$ & $\begin{array}{l}7.62 \\
7.63 \\
7.61 \\
7.53 \\
7.65 \\
7.32 \\
7.71\end{array}$ & $\begin{array}{l}56 \\
56 \\
56 \\
54 \\
55 \\
54 \\
57\end{array}$ & $\begin{array}{c}44 \\
46 \\
48 \\
{[160] \star} \\
43 \\
45 \\
45\end{array}$ & $\begin{array}{l}12 \\
17 \\
10 \\
16 \\
14 \\
15 \\
9.6\end{array}$ & $\begin{array}{l}1.6 \\
1.5 \\
1.6 \\
1.9 \\
1.6 \\
1.8 \\
1.5\end{array}$ & $\begin{array}{l}20 \\
20 \\
19 \\
25 \\
22 \\
26 \\
20\end{array}$ & $\begin{array}{l}0.02 \\
0.04 \\
0.04 \\
0.03 \\
0.10 \\
0.07 \\
0.06\end{array}$ & $\begin{array}{l}150 \\
150 \\
150 \\
170 \\
160 \\
180 \\
160\end{array}$ & $\begin{array}{l}20 \\
19 \\
19 \\
21 \\
20 \\
21 \\
19\end{array}$ & $\begin{array}{l}- \\
- \\
- \\
- \\
- \\
-\end{array}$ & $\begin{array}{l}- \\
- \\
- \\
- \\
-\end{array}$ & $\begin{array}{l}1.4 \\
3.2 \\
0.96 \\
0.66 \\
1.7 \\
0.38 \\
0.68\end{array}$ & $\begin{array}{l}2.2 \\
2.1 \\
2.1 \\
2.2 \\
2.1 \\
2.0 \\
2.2\end{array}$ & $\begin{array}{l}8.6 \\
9.3 \\
7.7 \\
9.9 \\
9.7 \\
9.7 \\
8.3\end{array}$ & $\begin{array}{r}2.3 \\
6.6 \\
6.5 \\
- \\
-0.2 \\
0.4 \\
-1.7\end{array}$ \\
\hline
\end{tabular}

* Sample probably cont aminated.

NA $=$ Not Analyzed. 
TABLE 4 Chemical Analyses (mg/L) of fiuids collected during experiments on Topopah Spring Tuff (continued).

\begin{tabular}{|c|c|c|c|c|c|c|c|c|c|c|c|c|c|c|c|c|}
\hline & Days & $\left(25^{\circ} \mathrm{C}\right)$ & $\mathrm{SiO}_{2}$ & $\mathrm{Na}$ & $\mathrm{k}$ & Mg & $\mathrm{Ca}$ & A 1 & $\mathrm{HCO}_{3}$ & $50_{4}$ & $\mathrm{NO}_{2}$ & $\mathrm{NO}_{3}$ & $\mathrm{PO}_{4}$ & $F$ & $\mathrm{Cl}$ & $\begin{array}{l}\text { Bal. } \\
(\%)\end{array}$ \\
\hline EXPERIMENT & & & & & & & & & & & & & & & & \\
\hline Room-Temperature & - & 7.51 & 110 & 57 & 25 & 2.6 & 24 & 0.14 & 170 & 28 & - & 6.4 & 2.9 & 3.0 & 22 & 4.6 \\
\hline 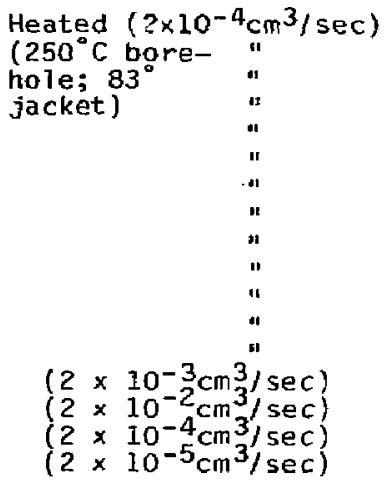 & $\begin{array}{r}0.89 \\
1.77 \\
2.81 \\
4.03 \\
6.75 \\
7.75 \\
8.74 \\
9.74 \\
10.75 \\
13.75 \\
14.74 \\
15.73 \\
16.74 \\
17.00 \\
17.06 \\
17.73 \\
20.73\end{array}$ & $\begin{array}{l}7.19 \\
7.31 \\
7.25 \\
7.65 \\
7.28 \\
7.20 \\
7.12 \\
7.12 \\
7.19 \\
7.23 \\
7.19 \\
7.10 \\
7.00 \\
7.46 \\
6.92 \\
7.27 \\
6.97\end{array}$ & $\begin{array}{l}120 \\
150 \\
150 \\
170 \\
220 \\
240 \\
250 \\
260 \\
270 \\
270 \\
270 \\
270 \\
270 \\
390 \\
410 \\
280 \\
250\end{array}$ & $\begin{array}{l}68 \\
66 \\
60 \\
55 \\
50 \\
50 \\
50 \\
50 \\
50 \\
50 \\
48 \\
48 \\
49 \\
43 \\
43 \\
47 \\
55\end{array}$ & $\begin{array}{l}54 \\
56 \\
53 \\
48 \\
43 \\
40 \\
38 \\
37 \\
36 \\
34 \\
32 \\
31 \\
30 \\
17 \\
9.2 \\
29 \\
33\end{array}$ & $\begin{array}{l}3.2 \\
2.8 \\
2.9 \\
2.5 \\
2.4 \\
2.3 \\
1.9 \\
2.0 \\
1.9 \\
2.0 \\
1.9 \\
1.9 \\
1.9 \\
0.93 \\
0.34 \\
1.1 \\
1.8\end{array}$ & $\begin{array}{l}44 \\
50 \\
56 \\
52 \\
52 \\
50 \\
47 \\
50 \\
51 \\
49 \\
44 \\
44 \\
43 \\
32 \\
17 \\
31 \\
40\end{array}$ & $\begin{array}{l}0.03 \\
0.02 \\
0.04 \\
0.05 \\
0.05 \\
0.04 \\
0.03 \\
0.05 \\
0.07 \\
0.07 \\
0.10 \\
0.08 \\
0.08 \\
0.05 \\
0.25 \\
0.08 \\
1.05\end{array}$ & $\begin{array}{l}240 \\
290 \\
310 \\
300 \\
290 \\
270 \\
270 \\
260 \\
260 \\
260 \\
250 \\
250 \\
250 \\
180 \\
110 \\
190 \\
270\end{array}$ & $\begin{array}{l}35 \\
27 \\
26 \\
24 \\
21 \\
20 \\
21 \\
21 \\
20 \\
20 \\
21 \\
20 \\
21 \\
19 \\
19 \\
20 \\
21\end{array}$ & $\begin{array}{l}- \\
- \\
- \\
\overline{-} \\
- \\
- \\
= \\
- \\
- \\
- \\
- \\
= \\
- \\
-\end{array}$ & $\begin{array}{l}9.3 \\
- \\
- \\
- \\
- \\
0.98 \\
- \\
\overline{-} \\
\overline{T r} \\
- \\
- \\
\overline{1.3} \\
0.18 \\
0.62\end{array}$ & $\begin{array}{l}6.0 \\
5.6 \\
3.6 \\
2.5 \\
2.2 \\
3.7 \\
1.7 \\
1.7 \\
1.4 \\
1.8 \\
2.3 \\
2.4 \\
1.7 \\
1.1 \\
0.66 \\
1.0 \\
1.3\end{array}$ & $\begin{array}{l}2.2 \\
1.5 \\
1.3 \\
1.3 \\
1.5 \\
1.5 \\
1.5 \\
1.5 \\
1.5 \\
1.5 \\
1.6 \\
1.6 \\
1.5 \\
2.1 \\
2.3 \\
2.0 \\
1.4\end{array}$ & $\begin{array}{l}40 \\
26 \\
21 \\
18 \\
13 \\
13 \\
11 \\
10 \\
10 \\
9.5 \\
9.4 \\
9.7 \\
8.8 \\
8.1 \\
7.6 \\
8.2 \\
8.9\end{array}$ & $\begin{array}{r}8.5 \\
10.9 \\
9.0 \\
5.7 \\
6.2 \\
8.5 \\
6.0 \\
12.4 \\
13.3 \\
10.8 \\
6.1 \\
5.7 \\
5.8 \\
6.9 \\
15.6 \\
12.8 \\
4.8\end{array}$ \\
\hline
\end{tabular}


anions analyzed with these fluids are somewhat low relative to the sums of cations; about one-third of the balances are at or above $+10 \%$. The precipitates were collected for examination, but the small amounts precluded identification. However, since bicarbonate was the only anion present in significant amounts in the other Topopah experiments, bicarbonate is the most likely anion to have been remaved in sufficient quantities to affect the solution balances.

Selected fluill analyses were analyzed with the SOLMNEQ computer program (Kharaka and Barnes, 1973) which computes the degree of saturation of the solutions with respect to many minerals as a function of temperature. The fluid compositions represent the state of the groundwater at its point of exit from the tuff; therefore, each fluid composition was analyad with SOLMNEQ at the prevailing jacket temperature. The composition of the discharged fluids is undoubtedly different from what it would be at intermediate points in the tuff; because of this, analyses at higher temperatures were not attempted. Values of $\Delta G_{R}$ obtained from the SOLMMEQ calculations are presented in Table 5 for some of the minerals most relevant to the tuff, including various silica phases, zeolites, clays and calcite. Positive values of $\Delta^{T_{R}}$ indicate that the solution is supersaturated with respect to the mineral considered; in Table 5, only the positive values of $\Delta G_{R}$ are listed. The results listed in Table 5 give an indication of the sorts of minerals that potentially could precicitate from the fluids at law temperatures onto the tuff.

\section{Discussion}

pH. Values of $\mathrm{pH}$ for all the fluid samples were between 6.9 and 8.1 (Table 4). Experiment 1 showed a slight trend to decreasing pH with time, the 
TABLE 5. Reaction states ( $\Delta G_{R}$, in $K c a l$ ) of selected fluid sampies at the low-temperature sides of the tuff cylinders. Only positive values of ${ }_{\triangle} \mathrm{G}_{R}$, indicating supersaturation, are included in the table.

\begin{tabular}{|c|c|c|c|c|c|c|c|c|c|c|c|c|c|}
\hline & \multicolumn{4}{|c|}{ EXPERIMENT $1\left(50^{\circ} \mathrm{C}\right)$} & \multicolumn{4}{|c|}{ EXPER IMENT $2\left(36^{\circ} \mathrm{C}\right)$} & \multicolumn{5}{|c|}{ EXPERIMENT $3\left(83^{\circ} \mathrm{C}\right)$} \\
\hline Mineral & $\begin{array}{l}0.15 \\
\text { Days }\end{array}$ & $\begin{array}{l}0.40 \\
\text { Days }\end{array}$ & $\begin{array}{l}10.85 \\
\text { Days }\end{array}$ & $\begin{array}{l}19.85 \\
\text { Days }\end{array}$ & $\begin{array}{l}\text { T.88 } \\
\text { Days }\end{array}$ & $\begin{array}{l}6.01 \\
\text { Days }\end{array}$ & $\begin{array}{l}7.97 \\
\text { Days }\end{array}$ & $\begin{array}{l}13.96 \\
\text { Days }\end{array}$ & $\begin{array}{l}\overline{0.89} \\
\text { Days }\end{array}$ & $\begin{array}{l}1.77 \\
\text { Days }\end{array}$ & $\begin{array}{l}10.75 \\
\text { Days }\end{array}$ & $\begin{array}{l}17.06 \\
\text { Days }\end{array}$ & $\begin{array}{l}20.73 \\
\text { Days }\end{array}$ \\
\hline
\end{tabular}

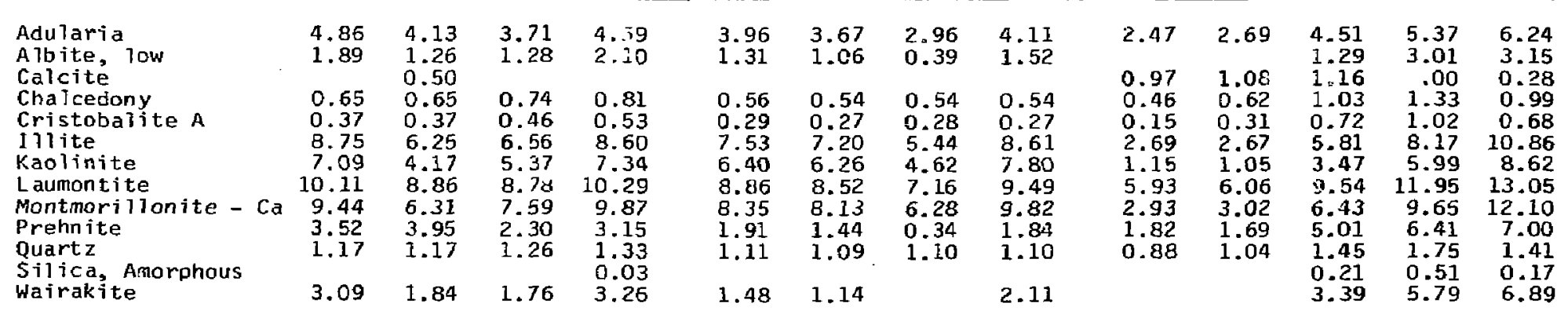


$\mathrm{pH}$ generally being above 7.5 during the first 10 days of the experiment and near 7.4 after 10 days. In addition, among the three experiments a tendency existed to increased $\mathrm{pH}$ with decreasing temperature. In experiment 3 , with a $250^{\circ} \mathrm{C}$ borehole temperature, most values of $\mathrm{pH}$ were between 7.1 and 7.3 . In experiment 1 (150 $\mathrm{C}$ borehole temperature), most measurements of $\mathrm{pH}$ were greater than 7.3 , and in experiment $3\left(90^{\circ} \mathrm{C}\right.$ borehole temperature) nearly all were greator than 7.5 .

Ionic Concentrations. Figure 3 plots the cinanges with time in the sum of cations in solution, expressed in milliequivalents per liter, for the three experiments; these plots illustrate what happens to the overall ionic concentrations during the course of the experiments. Cation sums for the $150^{\circ} \mathrm{C}$ experiment 1 and $90^{\circ} \mathrm{C}$ experiment 2 are comparable at values only slightly above $\mathrm{Jl} 3$ levels (Figure 3). The concentrations for experiment 3 were higher for the most part, a reflaction of the higher temperatures of that experiment. However, the amount of ionic material going into solution during experiment 3 also was a function of flow rate. During the first 16 days a constant flow rate of $2 \times 10^{-4} \mathrm{~cm}^{3} / \mathrm{sec}$ was maintained and cation sums showed a gradual decrease with time from about 7 meq/L to a relatively stable value of about $5.2 \mathrm{meq} / \mathrm{L}$. Following that, the rate of fluid flow was increased in two steps to $2 \times 10^{-2} \mathrm{~cm}^{3} / \mathrm{sec}$, causing the ionic concentrations of the discharged flujds to decrease markedly. Ait the fastest flow rate, the concentration was essentially that of the $\mathbf{J 1 3}$ groundwater. With the resumption of slower flow rates the cation sums returned to values above $5 \mathrm{meq} / \mathrm{L}$.

The effect of the amount of reaction time on solution concentrations also was investigated in experiment 2, in this case by stopping flow for periods of 25,50 , and 100 hours, as described previously. Samples of the fluids that had been in contact with the tuff during those times showed slight increases 

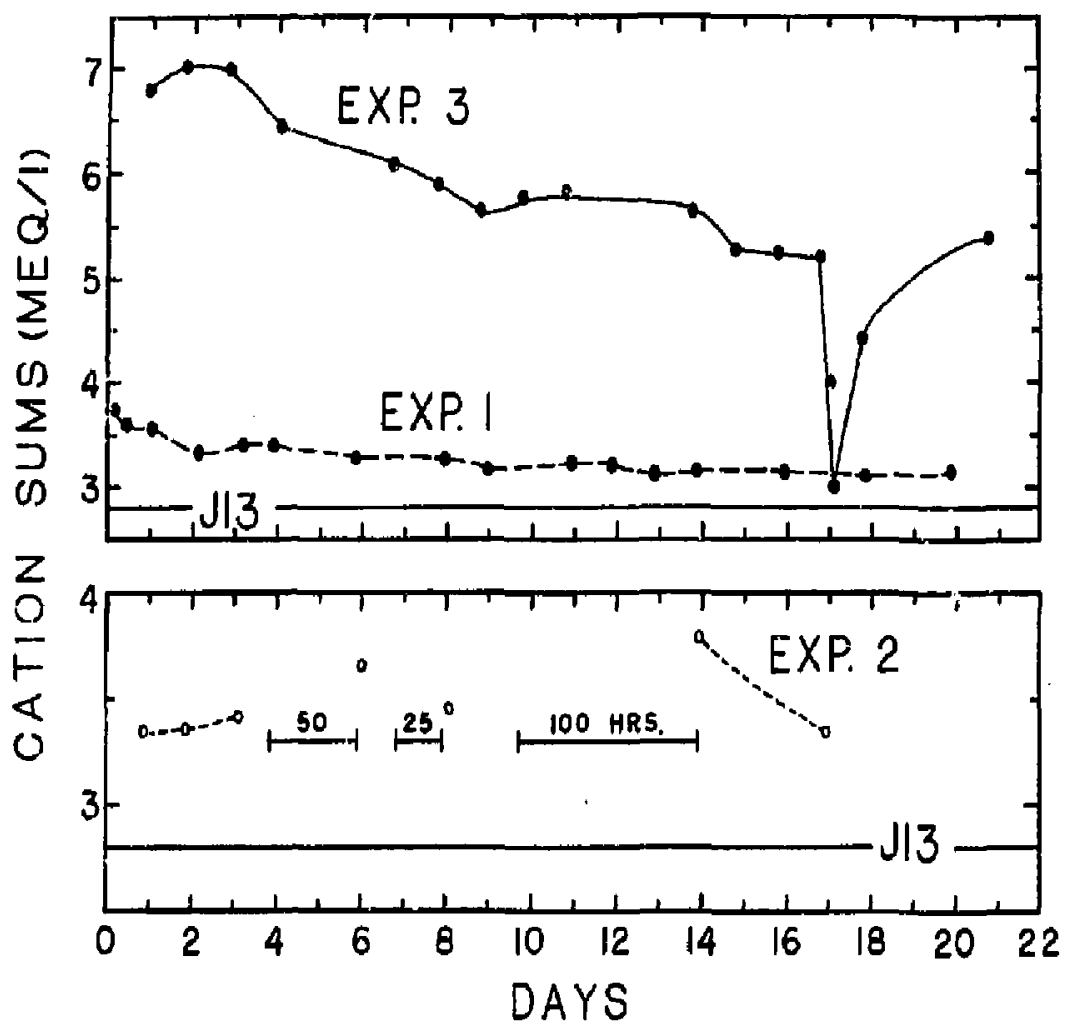

Fisure 3. Changes with time in the sum of cations (as an indication of ionic concentrations) in the fluid samples collected from the Topopan cyl inders during the three experiments. 
in their ionic concentrations over earlier samples, and the amount of increase varied directly with the amount of time that flow was stopped (Figure 3 ). Because of the low temperatures of this experiment, however, the proportional increase was considerably less than observed in experiment 3. Fcllowing 3 days of fluid flow after the 1C0-hour halt, the cation sums had returned to the levels of the first few days of the experiment.

Individual Species in Solution. Potassium (Figure 4), calcium, bicarbonate (Figure 5) and dissolved silica (expressed as $\mathrm{mg} / \mathrm{L} \mathrm{SiO} 2$ in Figure 6) were the principal species added to the $\$ 13$ water through interaction with the tuff cylinders during the three experiments. The $K$ and some $\mathrm{Ca}$ contributed to solution probably were derived from the dissolution of feldspars, the $\mathrm{HCO}_{3}$ and additional ca probably came from the calcite deposited in veins and voids, and the silica probably came from cristobalite, quartz, any remaining glass, and perhaps other sflicate minerals. In the nearly neutral solutions of these experiments (Table 4), dissolved silica occurs principally as non-ionized silicic acid.

With $\mathrm{K}, \mathrm{Ca}$, and $\mathrm{HCO}_{3}$ the major added ions, variations in their concentrations with time in the discharged fluids mirror the overall trends in ionic concentrations shown in Figure 3 , with lower values in the $90^{\circ}$ and $150^{\circ} \mathrm{C}$ experiments and higher values throughout much of the $250^{\circ} \mathrm{C}$ experiment. In experiments 2 and 3 , longer reaction times between the pore fluids and tuff cylinders led to higher concentrations in solution for each of these three ionic species. This behavior suggests that the main controls on these solution concentrations were dissolution reactions that were somewhat impeded at the faster flow rates. 


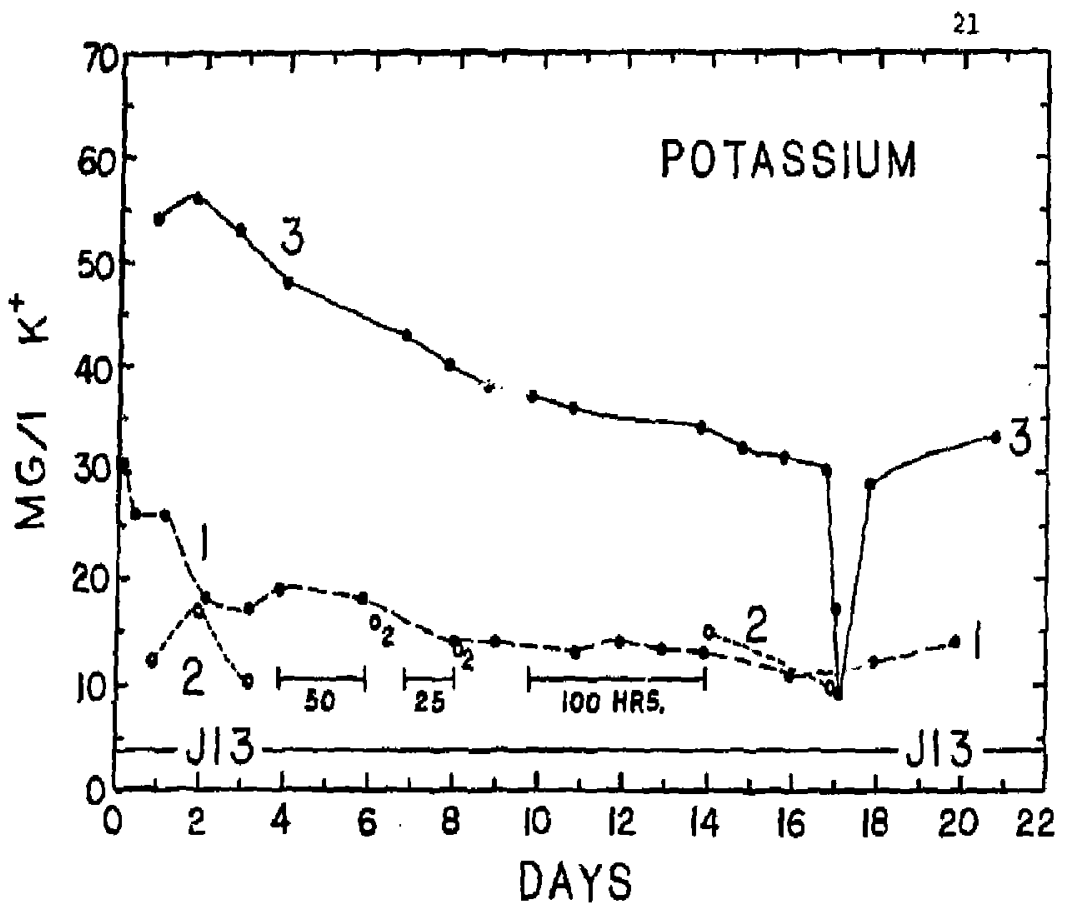

Figure 4. Potassium contents of the fluids collected during the three Topopah experiments.

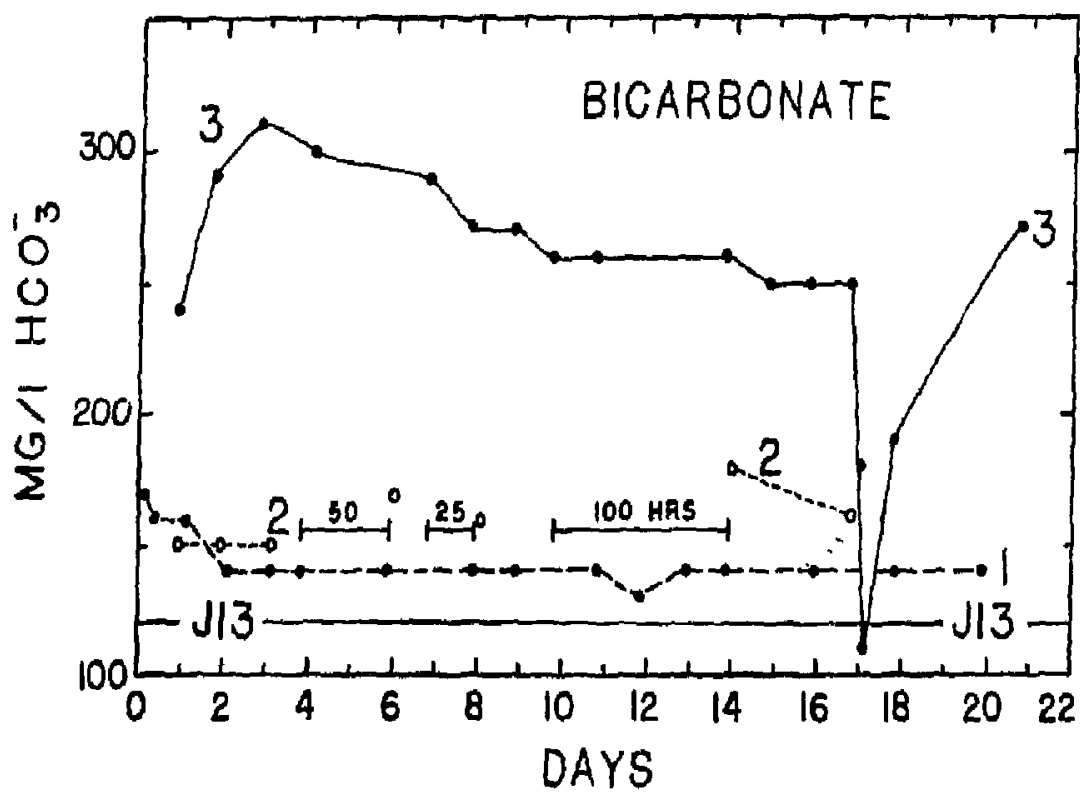

Figure 5. Changes in bicarbonate ion contents with time of the fluids discharged from the Topopah cylinders. 


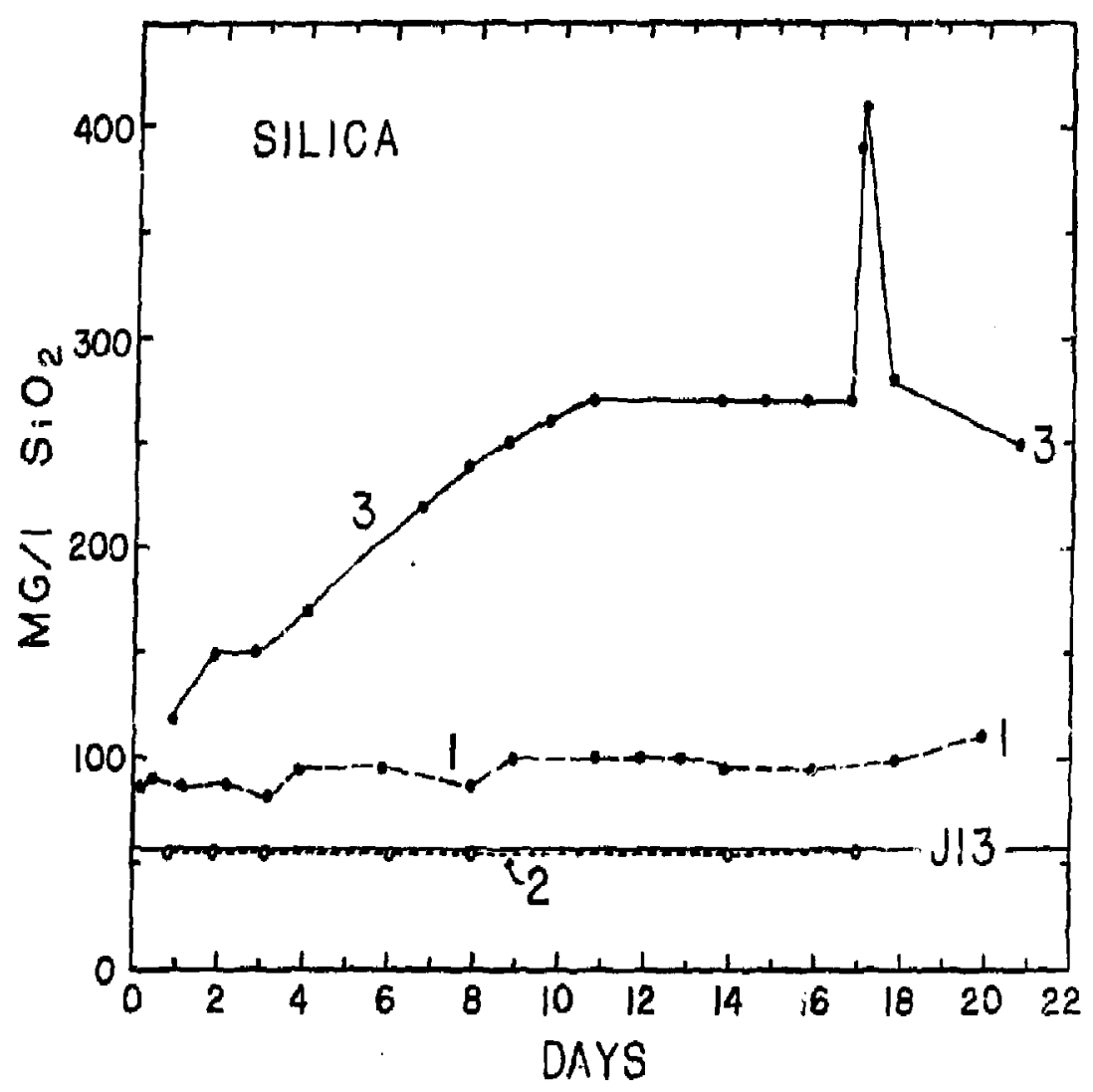

Figure 6. Dissolved silica contents of the fluids collected during the three experiments on Topopah. 
Throusghout experiment 3, enough $\mathrm{Ca}$ and $\mathrm{HCO}_{3}$ were added to the pore fluids to make the solutions supersaturated with calcite at the temperature of discharge from the tuffs (Table 5). Apparently, the rate of fluid flow was high enough to inhibit the precipitation of calcite at lower temperatures in the tuff.

The amount of silica in the discharged fluids was controlled by both dissolution and precipitation reactions. The results of the SOLAliEQ calculations (Table 5) show that the discharged fluids in all three experiments were supersaturated with respect to quartz and cristobalite at the outlet temperature. Fluids collected towards the end of experiments 1 and 3 also were supersaturated with amorphous silica. In the second part of experiment 3, the silica concentrations in solution slowed behavior opposite to the major ionic species in that silica increased rather than decreased with increasing flow rates. This different behavior for silica can be explained by the occurrence of relatively rapid dissolution reactions at higher temperatures in the tuff and relatively slower precipitation reactions at lower temperatures. The silica dissolution reactions could better ket. $_{r}$ "ace with the faster flow rates; as a result, the amount of silica in solution became higher rather than lower.

Some other specias also show evidence of participation in precipitation reactions because their concentrations in the discharged fluids were lower than the starting $\mathrm{J} 13$ values. Magnesium is a good example of this (Figure 7). Concentrations were below the 313 values throughout experiments 1 and 2 . In the first part of cyneriment 3 , Mg leveled out at the $\mathrm{Jl} 3$ level; as flow rates were increased, however, Mg was removed from the $\mathrm{Jl} 3$ water in orogressively greater amounts. As with dissolved silica, the behavior of $\mathrm{Mg}$ in solution 


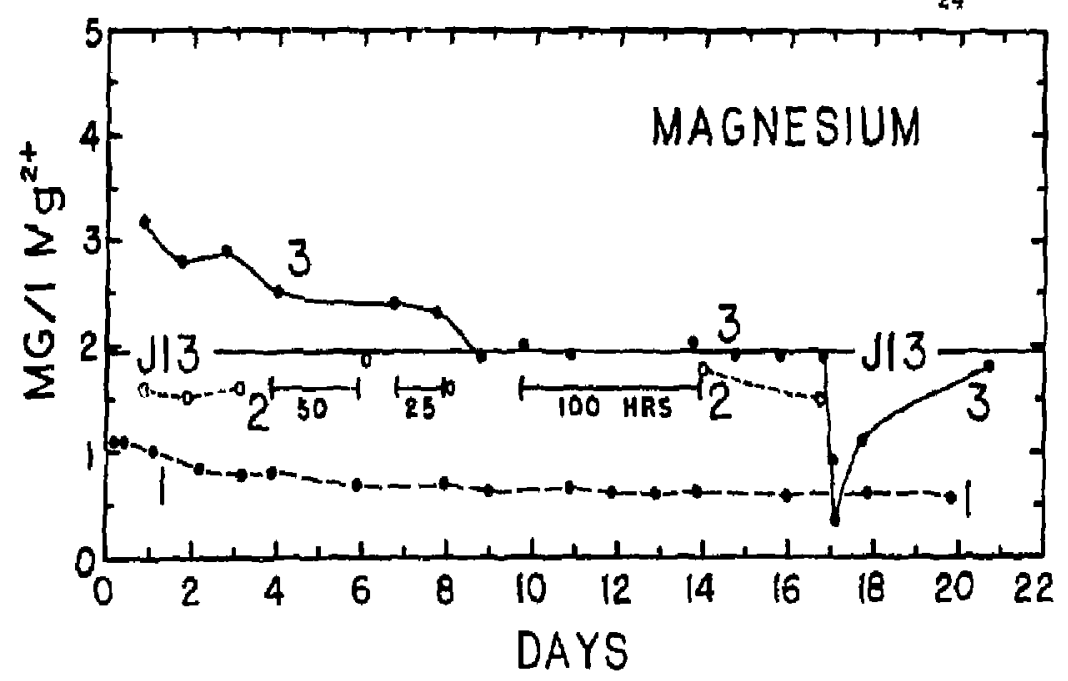

Figure 7. Magnesium contents of the fluids discharged from the Topopan samples during the three experiments.
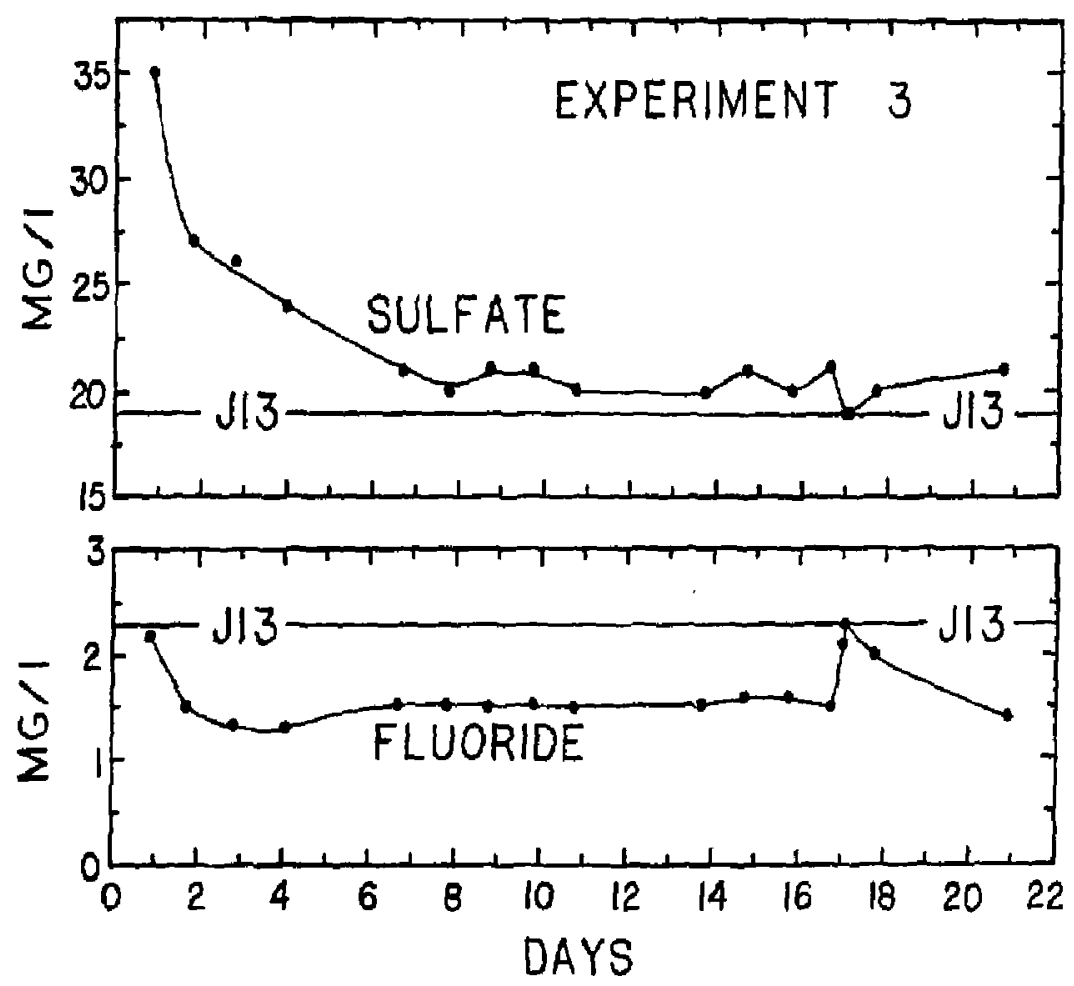

Figure 8. Changes in sulfate and fluoride content of the discharged pore flutds with time during experiment 3. 
during experiment 3 may have been the result of competing Mg-releasing and Mg-consuming reactions in the tuff. With $\mathrm{Mg}$, the higher flow rates inhibited the Mg-releasing reaction to a greater extent than it did the Mg-consuming one, thereby causing the shift to lower Mg concentrations.

Fluoride apparently was not available in minerals in the tuff to be contributed to solution. As a result, in experiments 1 and $2, F$ concentrations remained at 313 levels. In the higher-temperature experiment 3 , the concentrations of other ions in solution became sufficiently high that, combined with the J13 F concentration, the fluids became supersaturated with respect to some F-bearing mineral. The fluids were not supersaturated at the out let temperature with respect to any F-rich minerals, for example fluorite, contained in the mineral set in SOLMNEQ. However, the fluids may have been supersaturated at higher temperatures in the tuff, leading to precipitation of some F-bearing phase and lowering the amount of $F$ in the discharged fluids (Figure 8). When f low rates were increased during experiment 3 , the precipitation reaction was impeded and $F$ concentrations returned to $\$ 13$ values.

Dissolved species such as $\mathrm{SO}_{4}, \mathrm{Cl}$, and $\mathrm{NO}_{3}$ also are not contained in minerals in the tuff. Some small amount of these materials may have been contained in natural pore fluids or loosely adhered to grain boundaries in the tuff. Such materials were readily removed in the waters that passed through the tuff cylinders during the experiments, causing the concentrations of those species to increase somewhat above $\mathrm{J13}$ levels at the start of an experiment, as illustrated for $5_{4}$ in Figure 8 . The small supply of this intergranular material was quickly depleted with continued fluid flow, and concentrations returned to $\mathrm{J1} 3$ levels, where they remained relatively unaffected by changes 
in flow rate or halts in fluid flow. Unlike $F$, the solubilities of sulfateor chloride-bearing phases were not exceeded in any of the three experiments on Topopah. Nitrate did disappear from the J13 waters (Table 4). This loss may be a function of the instability of nitrate, which also is shown by the conversion of nitrate to nitrite during parts of the three experiments.

Aluminum is present in the smallest amounts of the species analyzed; all but one of the values were below about $0.3 \mathrm{mg} / \mathrm{L} \mathrm{Al}$, the single high value being at $1 \mathrm{mg} / \mathrm{L}$ (Table 4 ). In experiment 1 , the concentration of $A T$ in solution increased and decreased rather erratically with time. However, there was a slight overall tendency in experiment 1 to higher $A 1$ concentrations near the end of the experiment, the concentrations often being below $0.1 \mathrm{mg} / \mathrm{LA}$ during the first 10 days and for the most part above $0.1 \mathrm{mg} / \mathrm{L}$ thereafter. Somewhat clearer trends in Al concentration with time were observed in experiments 2 and 3. In experiment 2, Al was at or below $0.04 \mathrm{mg} / \mathrm{L}$ during the first 6 days and at or above $0.06 \mathrm{mg} / \mathrm{L}$ after that. During the constant flcw rate part of experiment 3 , Al concentrations were at most $0.05 \mathrm{mg} / \mathrm{L}$ during the first 10 days and subsequently at least $0.07 \mathrm{mg} / \mathrm{L}$. In the changing flow rate part of experiment 3, however, Al varied erratically between low and high values at both the slower and faster flow rates.

Even at the lowest Al concentrations measured, the fluids were supersaturated with respect to many Al-bearing minerals at the point of discharge from the tuffs (Table 5). Included in this group are many zeolites, clay minerals and alkali feldspar, phases which are found as diagenetic alteration minerais in Topopah (Waters and Carro11, 1981). 
COMPARISON WITH RESULTS FOR BULLFROG TUFF

Permeability experiments similar to those described above for the Topopah Spring Member of the Paintbrush Tuff also were conducted on the Bullfrog Member of the Crater Flat Tuff at the Nevada Test Site (Morrow et al., 1983; Byerlee et al., 1983). In the Bullfrog study, two experiments were run at a borehole temperatıre of $250^{\circ} \mathrm{C}$, using distilled water as the pore fluid in one experiment and $\mathrm{J}-13$ groundwater in the other. A third experiment was run at $150^{\circ} \mathrm{C}$ borehole temperature and with $\mathrm{J}-13$ water. Confining and pore pressures were kept the same in the Bullfrog and Topopah runs.

The initial permeabilities of the Bullfrog samples ranged from 0.5 to $8.5 \mu d a$, in comparison with 3 to $65 \mu \mathrm{da}$ for the Topopah samples. In cormon with the Topopah cylinders, the permeabilities of the Bullfrog samples showed slight to marked increases with initial heating, related to thermal cracking. The $150^{\circ} \mathrm{C}$ Bullfrog and Topopah cylinders then behaved similarly in showing no further changes in permeability. However, in the two $250^{\circ} \mathrm{C}$ Bullfrog experiments, following the initial increases, the permeabilities then decreased at first rapidiy and then more slowly back to or below the iritial, roomtemperature values.

Both the room-temperature and first heated fluids from the Bullfrog experiments had considerably higher pH (up to 10.6) and much larger amounts of dissolved materia? (Figures 9, 10) than fluids from the comparable Topopah experiments. Much of the material which contributed dissolved constituents to the early-samoled Bullfrog fluids had been loosely adhered to crystal surfaces and pore walls (Byerlee et a]., 1983) and as such was quickly removed from the 


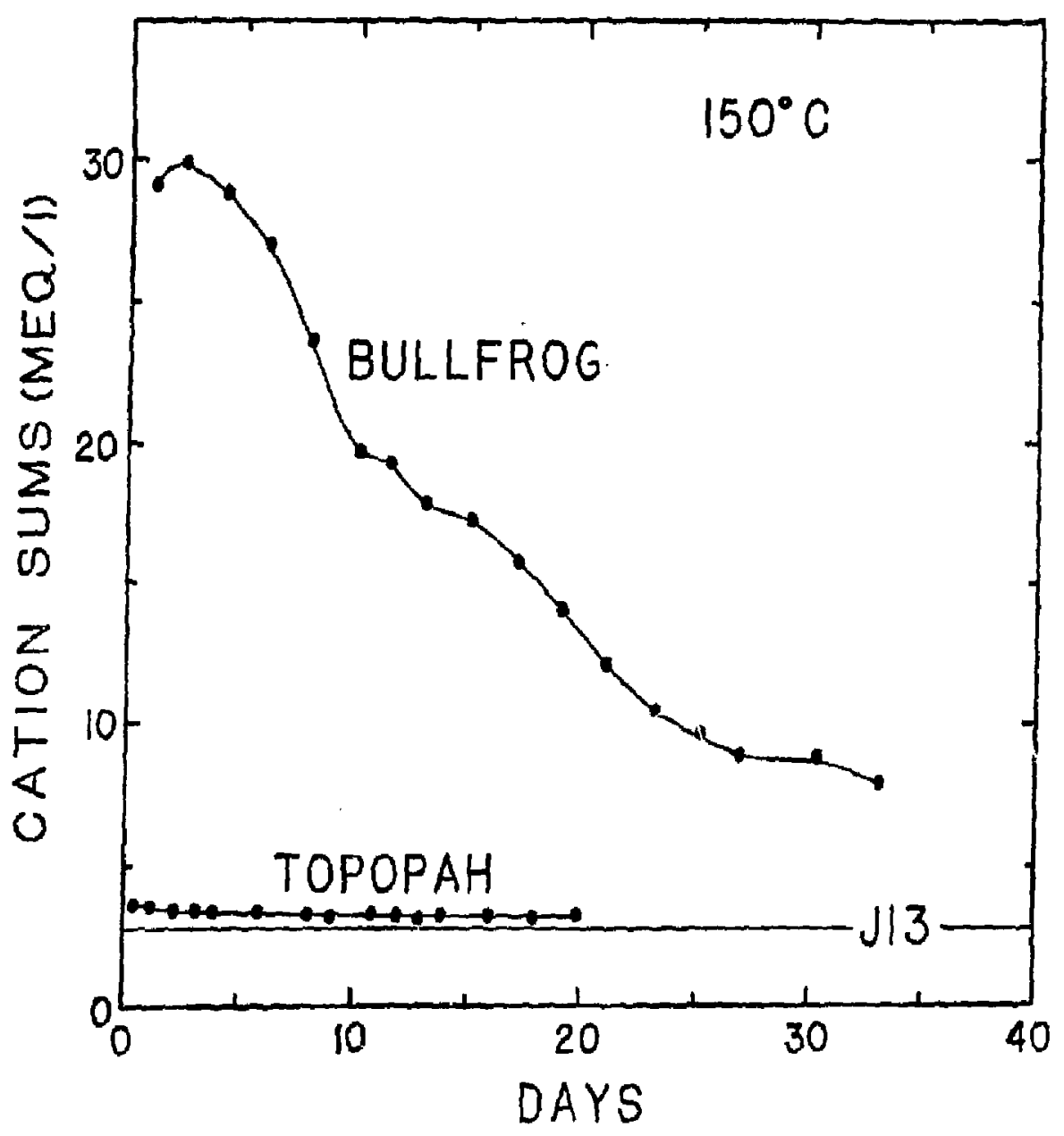

Figure 9. Comparison of the cation sums of the fluid samples from the Bullfrog and Topopah Spring Tuffs in experiments at $150^{\circ} \mathrm{C}$ borehole temperature. 


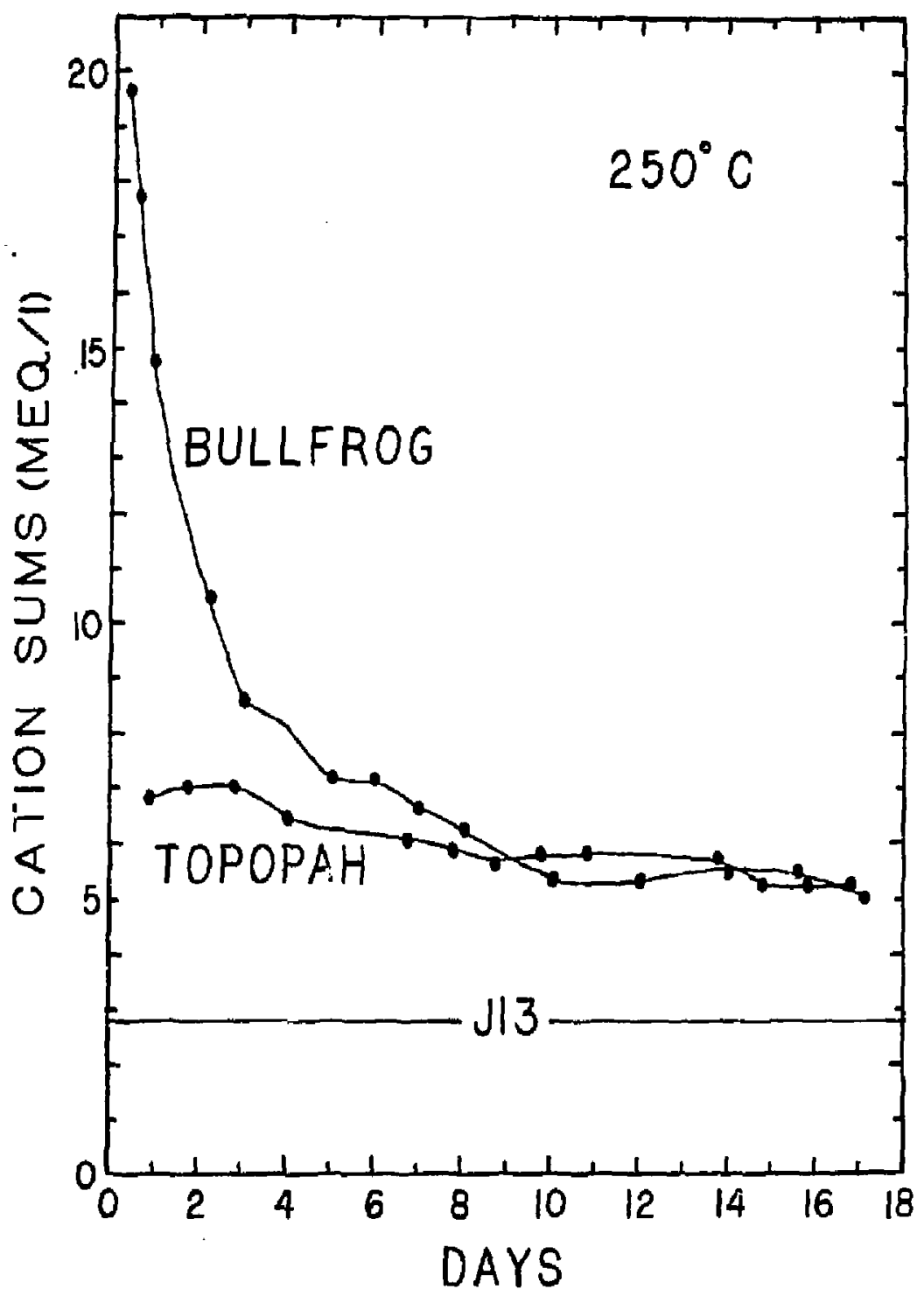

Figure 10. Comparison of the changes in cation sums with time of fluids collected during experiments at $250^{\circ} \mathrm{C}$ borehole temperature on the Topopah Spring and Bullfrog Tuffs, both using J.13 water as the pore fluid. 
tuff cylinders by the pore fluids. As a result, both the iunic concentrations and $\mathrm{pH}$ of the Bullfrog solutions decreased with time to values much closer to those of the Topopah experiments (Figures $:, 10$ ).

Although the total ionic concentrations became more similar, some differences remained with respect to the specific ions present in the Bullfrog and Topopah fluids. Sodium was the principal cation of the Bullfrog solutions, whereas $\mathrm{Ca}$ and $\mathrm{K}$ were the major cations added to the J-13 water in the Topopah experiments. Bicarbonate ion was the principal anion throughout the Topopah experiments. A carbonate species also was important in the Bullfrog solutions; because of their relatively high $\mathrm{oH}$, the early-sampled fluids contained considerable arlounts of carbonate as well as bicarbonate ion. Similarly, some of the dissolved silica became ionized in the high-pH Bullfrog fluids, contributing large amounts of $\mathrm{H}_{3} \mathrm{SiO}_{4}^{-1}$ and lesser amounts of $\mathrm{H}_{2} \mathrm{SiO}_{4}^{-2}$ to solution. This caused the intal silica contents of the Bullfrog solutions to be much higher than those of the Topopah fluids; however, the non-ionized portions of the silica contents were similar in comparabla Bullfrog and Topopah experiments. As the pH of the Bullfrog fluids decreased with time, the amounts of $\mathrm{CO}_{3}^{-2}, \mathrm{H}_{2} \mathrm{SiO}_{4}^{-2}$, and $\mathrm{H}_{3} \mathrm{SiO}_{4}^{-1}$ in solution also decreased.

\section{CONCLUSIONS}

At the Nevada Test Site, a potential disposal site in the Topopah Spring Member would be situated in the unsaturated zone above a deep-lying water table. The advantage to such a disposal scheme would be that the canisters would not be in continuous contact with heated groundwater. One of the requirements for the host tuff, therefore, would be that any groundwaters 
percolating down to the disposal horizon should be able to move freely past the canisters and not be trapped around them. The groundwaters themselves should be unreactive.

The results of this study on the Topopah Spring Membar appear satisfactory to such a disposal scheme. The conditions of these experiments would represent an extreme case for disposal in the tuff, since the rock samples must be saturated in order to make the permeability measurements. The results show that the initial permeability of the tuff is relatively high, compared to rocks such as granodiorite (Moore et al., 1983). Thus, any groundwaters in the tuff will not at first experience any significant impediments as they percolate past the canisters. With increased time, the tuff and associated groundwaters around the canisters will become heated. However, as these experiments show, heating to temperatures of at least $150^{\circ} \mathrm{C}$ has little effect on permeability. The modest inferred mineral growth and other mineral reactions occurring in the tuff apparently cause little change in permeability. In addition, the $\mathrm{J}-13$ groundwater from the Nevada Test Site is itself very dilute, and the interaction of the groundwater with the Topopah Member at temperatures to $250^{\circ} \mathrm{C}$ causes only minor changes in its compasition. 


\section{SUMMARY}

1. Permeability measurements made on samples of the Topopah Spring Member of the Paintbrush Tuff at room-temperature and in a temperature gradient show that the initially high (3 65 $\mu \mathrm{da})$ permeabilities are littie affected by heating to at least $150^{\circ} \mathrm{C}$. These permeability relationships are favorable for the disposal of nuclear waste in this tuff in an unsaturated zone at the Mevada Test Site.

2. The fluids discharged from the samples of tuff during the experiments are dilute, nearly neutral solutions that differ only slightly from the starting groundwater composition.

\section{ACKNOHLEDGMENTS}

This work was performed for Lawrence Livermore Laboratories under Contract Number SANL 126-016. 
References

American Society for Testing and Materials (1974) Annual Book of ASTM, Part 31 [water]. Philadelphia, PA, $902 \rho p$.

Barnes, R. B. (1975) The determination of specific forms of aluminum in natural water. Chem, Geology 15, 177-191.

Byerlee, J., Morrow, C., and Moore, D. (1983) Permeability and pore-fluid chemistry of the Bullfrog Tuff in a temperature gradient: Sumary of Results. U.S. Geological Open-File Report 83-475, $26 \rho \rho$.

Keith, L. A., Delaney, P. T., and Moore, D. E. (1983) Permeability reduction due to precipitation of quartz under nonisothermal conditions. Proceedings Ninth Stanford Geothermal Workshop.

Kharaka, Y. K. and Barnes, I. (1973) SOLMNEQ: Solution-mineral equilibrium computations. NTIS, U.S. Depart. Commerce, PB-215 899, 81 pp.

Moore, D. E., Morrow, C. A., and Byerlee, J. O. (1983) Chemical reactions accompanying fluid flow through granite held in a temperature gradient, Geochim. Cosmochim. Acta 47, 445-453.

Morrow, C., Moore, D., and Byerlee, J. (1983) Permeability and pore-fluid chemistry of the Bullfrog Tuff in a temperature gradient. Proc. 24th U.S. Symposium on Rock Mechanics, pp. 819-828.

Waters, A., and Carroll, D. (1981) Preliminary stratigraphic and petrographic characterization of core samples from USW-G1, Yucca Mountain, Nevada, Los Alamos National Laboratory, LA-8840-MS, Los Alamos, New Mexico. 